\title{
BACTERIA FOR COTTON PLANT PROTECTION: DISEASE CONTROL, CROP YIELD AND FIBER QUALITY ${ }^{1}$
}

\author{
HENRIQUE MONTEIRO FERRO ${ }^{2}$, RICARDO MAGELA DE SOUZA ${ }^{3}$, FLAVIA MARA VIEIRA LELIS ${ }^{3}$, JULIO \\ CARLOS PEREIRA DA SILVA ${ }^{4}$, FLÁVIO HENRIQUE VASCONCELOS DE MEDEIROS ${ }^{3 *}$
}

\begin{abstract}
Ramulosis (Colletotrichum gossypii var. cephalosporioides) is an important fungal disease of cotton in Brazil, exclusively controlled by fungicide application. Therefore, sustainable management of ramulosis is essential. This work aimed to evaluate the potential of three bacterial strains, Bacillus amyloliquefaciens (UFLA285), Bacillus velezensis (UFLA401), and Paenibacillus lentimorbus (MEN2), for the biocontrol of ramulosis in cotton and their effects on yield and fiber quality. Seed treatment (ST), foliar spray, and soil drenching application methods were used (separately or combined) under greenhouse and field conditions. Chemical treatments recommended against ramulosis and water were used as controls. Under greenhouse conditions all strains reduced the disease incidence. While $B$. velezensis UFLA401 and $P$. lentimorbus MEN2 reduced the incidence by $56.6 \%$ and $45.7 \%$, respectively, independent of the application method, B. amyloliquefaciens UFLA285 reduced the disease by about $60 \%$ when applied as a foliar spray or ST + foliar spray. Two field trials were performed and all bacterial strains reduced ramulosis incidence. In the first year, $B$. velezensis UFLA401 sprayed on the plants reduced incidence by $22.3 \%$ and ST + two foliar sprays resulted in the best performance, decreasing ramulosis by $57 \%$. In both seasons the yield increased by using either bacterial or chemical treatments compared to the water control. The combination B. velezensis UFLA401 and $P$. lentimorbus MEN2 sprays provided better fiber quality than chemical treatment. Therefore, Bacillus $s p$. (UFLA285 and UFLA401) and P. lentimorbus MEN2 are potential tools to reduce ramulosis, increase cotton yield and fiber quality.
\end{abstract}

Keywords: Biocontrol. Gossypium hirsutum. Bacillus sp. Disease control.

\section{USO DE BACTÉRIAS PARA PROTEÇÃO DO ALGODOEIRO: CONTROLE DE DOENÇAS, PRODUTIVIDADE E QUALIDADE DE FIBRAS}

\begin{abstract}
RESUMO - A ramulose (Colletotrichum gossypii var. cefalosporioides) é uma importante doença do algodão no Brasil cujo controle depende do uso de químicos. Portanto, práticas alternativas para o manejo sustentável da doença são cada vez mais necessárias. Esse trabalho objetivou verificar o potencial de três isolados bacterianos: Bacillus amyloliquefaciens (UFLA285), Bacillus velezensis (UFLA401) e Paenibacillus lentimorbus (MEN2) no controle de ramulose em algodoeiro. Três métodos de aplicação (tratamento de sementes (TS), pulverização foliar e aplicação no solo foram testados (separadamente ou combinados) em casa de vegetação e no campo. Fungicidas químicos e água foram usados como controles. Em casa de vegetação todos os isolados reduziram a severidade da ramulose, sendo que os isolados B. velezensis UFLA401 e $P$. lentimorbus MEN2 reduziram em 56.6\% e 45.7\%, respectivamente, independente do modo de aplicação. O isolado B. amyloliquefaciens UFLA285 reduziu a severidade em $62.1 \%$ pela pulverização foliar ou por TS + pulverização foliar. Dois ensaios de campo foram realizados e os três isolados testados reduziram a severidade da doença. No primeiro ano, B. velezensis UFLA401 reduziu a severidade em $22.3 \%$ por pulverização foliar e em $57 \%$ pot TS + duas pulverizações. A produtividade aumentou para todos os tratamentos comparados ao controle com água. A combinação B. velezensis UFLA401 and P. lentimorbus MEN2 em TS + duas pulverizações foliares aumentou a qualidade da fibra do algodão. Conclui-se que isolados de Bacillus sp. (UFLA285 e UFLA401) e P. lentimorbus MEN2 apresentam potencial para proteger o algodoeiro contra a ramulose e melhorar a produção e qualidade da fibra.
\end{abstract}

Palavras chave: Biocontrole. Gossypium hirsutum. Bacillus sp. Manejo de doenças.

\footnotetext{
${ }^{*}$ Corresponding author

${ }^{1}$ Received for publication in $11 / 22 / 2018$; accepted in $12 / 02 / 2019$.

Paper extracted from the master thesis of the first author.

${ }^{2}$ Vittia Group, São Joaquim da Barra, SP, Brazil; henriqueferro@vittia.com.br - ORCID: 0000-0002-5412-7344.

${ }^{3}$ Department of Plant Pathology, Universidade Federal de Lavras, Lavras, MG, Brazil; rmagelas@ufla.br - ORCID: 0000-0003-4667-3502, fvieiralelis@yahoo.com.br - ORCID: 0000-0002-2693-3824, flaviomedeiros@ufla.br-ORCID: 0000-0003-0993-796X.

${ }_{4}^{4}$ Department of Phytosanitary Defense, Universidade Federal de Santa Maria, Santa Maria, RS, Brasil; julio.c.silva@ufsm.br - ORCID: 0000-0002-1961-6695.
} 


\section{INTRODUCTION}

Cotton production has great importance in Brazil due to its economic and social impact and because it plays an important role in crop rotation with soybean and maize. However, cotton pest and disease management is always a challenge as their impact change over time (HILLOCKS, 2010). In this regard, the ramulosis disease, caused by the fungus Colletotrichum gossypii var. cephalosporioides (CGC), has long been one of the major diseases of Brazilian cotton (SALUSTIANO et al., 2014). As a seed-borne disease, ramulosis is currently widespread throughout the country and has been introduced into new areas of production (ARAÚJO et al., 2009). Symptomatic plants usually exhibit shortened internodes and abnormal sprouting of lateral buds that, ultimately, lead to devastating yield losses (up to $73 \%$ ) under conducive environmental conditions (MONTEIRO et al., 2009). In an attempt to mitigate yield losses, chemical fungicides have been extensively applied throughout the whole crop cycle (ZANCAN et al., 2013). Therefore, control of ramulosis exclusively by the chemicals could lead to an eventual disease outbreak due to resistance acquirement against fungicides. Furthermore, the exclusive use of chemicals leads to environmental contamination.

Alternative products for cotton disease management need to be developed. In this context, biological control agents are promising options for alternative and sustainable disease management (CAMPANHOLA; BETTIOL, 2003; SHAFI; TIAN; JI, 2017). The biocontrol of plant diseases is an important strategy in integrated disease management. Antagonistic microorganisms, such as many bacterial strains, play a key role in fungal resistance management and the replacement of chemical application, due to their broader spectrum of action. Moreover, the use of antagonistic bacteria positively affects the drought tolerance, plant growth, and yield of many agricultural crops (MARTINS et al., 2013; MARTINS et al., 2018a; MARTINS et al., 2018b). Among the bacterial agents able to be used in field conditions, many strains belong to the genus Bacillus and the use of antagonistically important Bacillus species and their commercial production has increased very rapidly in the last few years (REISS; JØRGENSE, 2017; SHAFI; TIAN; JI, 2017). These endosporogenic bacteria have a unique ability to replicate rapidly and resist to adverse conditions in aerial parts of crops and, in addition, a broad spectrum of plant-pathogen targets are venerable to their multiple mechanisms of attack (FIRA et al., 2018). Such aspects and positive control results have made Bacillus strains the most studied bacteria against foliar diseases (REISS; JØRGENSE, 2017).

Beneficial strains of Bacillus species could also be applied in organic cotton production. Lately, there has been an increasing market demand for organic cotton, encouraged by consumer interest and industry certification standards (FONTES et al., 2006; RIEPLE; SINGH, 2010). Organic fibers are used in a variety of products and organic cottonseeds are used for animal feed and organic oil production.

Previous studies regarding biological agents for the control of diseases in cotton have been made (NAWAZ et al., 2018; SILVA et al., 2017; YASMIN; HAFEEZ; RASUL, 2014) but they did not include ramulosis. Furthermore, the adoption of biocontrol agents for disease management may have an additional effect on plant growth (IRIZARRY; WHITE, 2017) and fiber quality. Therefore, the present study aimed to evaluate the potential of bacterial strains of Bacillus velezensis, Bacillus amyloliquefaciens and Paenibacillus lentimorbus against ramulosis in combination with their effect on the yield and fiber quality of cotton under different application methods.

\section{MATERIALS AND METHODS}

\section{Origin, storage and growth conditions and identification of bacterial strains}

The bacterial strains used in this study were Bacillus sp. UFLA401, Paenibacillus lentimorbus MEN2 and Bacillus amiloquefaciens UFLA285. These strains were isolated from the cottonproducing fields in the state of Mato Grosso (Brazil) (MEDEIROS et al., 2008; MEDEIROS et al., 2011), where they controlled damping-off and bacterial blight of cotton by seed treatment. For each trial, long-term preserved strains were briefly transferred from glycerol at $-80{ }^{\circ} \mathrm{C}$ (LAZO; GABRIEL, 1987) to nutrient agar medium and subsequently incubated at $28{ }^{\circ} \mathrm{C}$ for $48 \mathrm{~h}$. Then, individual cells were selected and inoculated into nutrient broth followed by incubation at $28{ }^{\circ} \mathrm{C}$ for $48 \mathrm{~h}$ with constant agitation at $150 \mathrm{rpm}$ in an incubation shaker. The inoculum concentration was routinely adjusted to $10^{8}$ endospores/mL using a Neubauer chamber.

The molecular characterization of Bacillus strain UFLA401 was by using pure bacterial colonies transferred to Medium 523 broth and incubated for $18 \mathrm{~h}$ at $28{ }^{\circ} \mathrm{C}$ with an agitation speed of $120 \mathrm{rpm}$. After overnight incubation the DNA was isolated as described by Wilson (1987) REP primers (REP1R-I 5' IIIICGICGICATCIGGC 3' and REP2-I 5' ICGICTTATGIGGCCTAC 3') (VERSALOVIC et al., 1991; VERSALOVIC et al., 1994) were used to amplify specific conserved repetitive sequences. The reaction were performed in a final volume of $50 \mu \mathrm{L}$ of a mixture containing $5 \mu \mathrm{L}$ of $5 \mathrm{X}$ Colorless GoTaq $^{\mathrm{TM}}$ Reaction Buffer (Promega, Wisconsin USA), $3 \mu \mathrm{L}$ of $\mathrm{MgCl}_{2}$ Solution $(25 \mathrm{mM}), 2 \mu \mathrm{L}$ of dNTP $(5 \mathrm{mM}), 2 \mu \mathrm{L}$ of each primer F/R $(10 \mu \mathrm{M})$, $30.5 \mu \mathrm{L}$ of water, $0.5 \mu \mathrm{l}$ of $\mathrm{GoTaq}^{\mathrm{TM}}$ DNA Polymerase $(5 \mathrm{u} / \mu \mathrm{L})$ (Promega, Wisconsin USA) and 
$5 \mu \mathrm{L}$ of DNA (100 ng). The thermocycling conditions consisted of an initial denaturation at $95{ }^{\circ} \mathrm{C}$ for $6 \mathrm{~min}$, followed by 35 cycles consisting of denaturation at $94{ }^{\circ} \mathrm{C}$ for $1 \mathrm{~min}$, annealing at $44{ }^{\circ} \mathrm{C}$ for $1 \mathrm{~min}$, and extension at $65^{\circ} \mathrm{C}$ for $8 \mathrm{~min}$, and a final extension at $65{ }^{\circ} \mathrm{C}$ for $16 \mathrm{~min}$. Amplified DNA was detected by electrophoresis in a $1 \%$ agarose gel containing GelRed (Biotium, California USA). The fragment of $\sim 1405 \mathrm{bp}$ amplified by the REP1R-I/ REP2-I primers was purified using Wizard $^{\mathrm{TM}}$ Genomic DNA Purification Kit (Promega, Wisconsin USA), it was also cloned into the pGEM $^{\mathrm{TM}}$-T Easy vector (Promega, Wisconsin USA) and sequenced by Macrogen, Korea. The sequences data were trimmed, assembled and identified based on the match obtained on BLAST NCBI. The GenBank BLAST tool showed that the strain UFLA401 was $99 \%$ similar to 236 Bacillus velezensis strain NKG-1, 190 B. amyloliquefaciens subsp. amyloliquefaciens KHG19 and 217 B. subtilis strain ATCC 19217. To confirm its identity studies using other genes should be performed but for now we have adopted the B. velezensis as the UFLA401 species.

Origin, storage and growth conditions of Colletotrichum gossypii var. cephalosporioides (CGC)

The strain CGC1, was obtained from the fungal culture collection of the seed pathology laboratory of the Universidade Federal de Lavras, Brazil. For inoculum preparations, CGC1 was routinely grown on potato dextrose agar (PDA) at $25{ }^{\circ} \mathrm{C}$ for 10 days. Conidium suspensions were diluted in sterile saline buffer $(0.85 \% \mathrm{NaCl})$ and initial concentrations adjusted to $10^{6}$ conidium $/ \mathrm{mL}$ in a Neubauer chamber (DIEZ et al., 2007).

\section{Ramulosis control under greenhouse conditions}

The Bacillus spp. and P. lentimorbus strains were tested for the control of ramulosis during two consecutive years (2009 and 2010) under greenhouse conditions at the plant pathology department of Universidade Federal de Lavras. The environmental conditions in the greenhouse were automatically controlled $\left(28^{\circ} \mathrm{C}\right.$ and $85 \%$ Relative humidity). The experiments were conducted in $5 \mathrm{~L}$ plastic pots containing commercial potting mix Plantmax ${ }^{\mathrm{TM}}$ ( $60 \%$ pine bark, $15 \%$ vermiculite and $25 \%$ humus). The bacterial treatments consisted of seed treatments followed by seedling sprays (ST + spray), seedling sprays only (Spray) and seed treatment followed by drenching applications (ST + Drenching). All bacterial suspensions were regulated to $10^{8}$ endospores $/ \mathrm{mL}$.

The highly-susceptible cotton cultivar Deltaopal was used in all trials. Briefly, cotton seeds were surface sterilized in a $2 \%$ bleach solution for
2 min. Treated seeds were microbiolized with the antagonists at a concentration of $2 \mathrm{~mL} / \mathrm{g}$ of seeds and left to dry for $12 \mathrm{~h}$ at room temperature. Afterward, seeds were sown in $5 \mathrm{~L}$ plastic pots containing commercial potting mix Plantmax ${ }^{\mathrm{TM}}$. Fertilizer was added uppon sowing by using N:P:K (20:10:10) solid fertilizer as recommended in technical field applications (FREIRE, 2007). The potting mix moisture level was adjusted initially to $60 \%$ of field capacity and the plants were watered three times a week with a hose. In the sprayed treatments cotton seedlings at the stage of the first expanded leaf (21 days after emergence and 7 days before CGC inoculation) were sprayed weekly with $1.5 \mathrm{~mL}$ of the bacterial suspensions using a hand sprayer ( $5 \mathrm{~mL}$ capacity) for a total of three applications. The soil drenching was performed by applying $5 \mathrm{~mL} /$ seedling at the stage of the first expanded leaf. As controls, the fungicide Pyraclostrobin (Comet $^{\mathrm{TM}}$, Basf Corp., Ludwigshafen, Germany; $3 \mathrm{~mL}$ a.i./L), the plant activator Acibenzolar-S-methyl (ASM) (Bion $500^{\mathrm{TM}}$, Syngenta, Basel, Switzerland) (7.5g a.i./100L) or water were used. The fungicide was sprayed twice, 7 days before and 7 days after CGC inoculation. The other controls (ASM and water) were sprayed 7 days before CGC inoculation. The pathogen (strain CGC1) was inoculated until run-off onto 28-day-old cotton seedlings (phenological growth stage V2) with inoculum suspensions of $10^{6}$ conidium/mL (BARROCAS; CRUZ; CARVALHO, 2011). Inoculated plants were immediately transferred to a moisture chamber and kept there for $24 \mathrm{~h}$.

Disease incidence was assessed at 7, 14, 21 and 28 days after inoculation. The incidence data were used to generate the mean value of lesioned leaves per replicate (two plants were evaluated per replicate) and then the area under the incidence progress curve (AUIPC) was estimated (SHANER; FINNEY, 1977). After the final evaluation, plants were removed from the soil and left to dry at a constant temperature of $70{ }^{\circ} \mathrm{C}$. The dry-weight mass of each plant aerial part was determined as a measure of plant growth.

\section{Ramulosis control under field conditions}

The strains of Bacillus spp. and $P$. lentimorbus were evaluated as potential biocontrol agents for the control of ramulosis in a commercial cotton field, during the 2008/2009 and 2009/2010 growing seasons. The row spacing was $0.45 \mathrm{~m}$ (8 plants $/ \mathrm{m})$, which allowed a favorable plant density for the natural development of ramulosis, avoiding the need for artificial inoculation. Trials were performed in a farm of Presidente Olegário, MG, Brazil at $987 \mathrm{~m}$ altitude, $18^{\circ} 05^{\prime} 21^{\prime \prime} \mathrm{S} 46^{\circ} 29^{\prime} 16^{\prime \prime} \mathrm{W}$. The experiments started by sowing the cotton (Deltaopal cultivar) seeds in December 2008. All crop management, such as physicochemical and

Rev. Caatinga, Mossoró, v. 33, n. 1, p. 43 - 53, jan. - mar., 2020 
fertilization practices, was performed by the farmer in a conventional crop system according to technical recommendations until harvest (FREIRE, 2007; ISHIDA et al., 2008).

The bacterial treatments encompassed: $B$. amyloliquefaciens UFLA285, B. velezensis UFLA401, $P$. lentimorbus MEN2 and B. velezensis UFLA401 $+P$. lentimorbus MEN2 (half of each concentration). The concentration of bacterial suspensions was $10^{8}$ endospores $/ \mathrm{mL}$ for all treatments.

The seed treatment adopted for field trials consisted of bacterial suspensions $\left(10^{8}\right.$ endospores/ $\mathrm{mL}$ ) along with agrochemicals routinely used for seed treatment, except fungicides. The agrochemicals included the insecticides carbofuran (Furadan $^{\text {TM }} 350 \mathrm{FS}$, FMC Washington, USA; $2.0 \mathrm{~L}$ c.p. $/ 100 \mathrm{~kg}$ of seeds) and thiamethoxam (Cruiser ${ }^{\mathrm{TM}}$ $600 \mathrm{FS} ; 600 \mathrm{~mL}$ c.p./100 kg of seed; Syngenta, Basel, Switzerland) and the seed protector diethylphosphorothioate (Permit $^{\mathrm{TM}} 500$ DS, FMC Washington, USA; $1.2 \mathrm{Kg}$ c.p./100 kg of seed). The seeds were piled with polyvinyl acetate glue $(150 \mathrm{~mL} / 100 \mathrm{~kg}$ of seeds).

In the first trial at season of 2009 , the foliar sprays consisted of five applications of bacterial treatments and controls. The first spray application was 30 days after planting (DAP) $(200 \mathrm{~L} / \mathrm{ha})$ with a 25-day interval between applications. In the second assay, in 2010 season, inoculation with antagonists was performed using three different methods; i) Seed treatment (1.2 L/100 kg of seeds); ii) Seed treatment (1.2 L/100 kg of seeds) +1 foliar spray 30 DAP (200 $\mathrm{L} / \mathrm{ha})$; Seed treatment $(1.2 \mathrm{~L} / 100 \mathrm{~kg}$ of seeds $)+2$ foliar sprays $(200 \mathrm{~L} / \mathrm{ha})$ with a 30-day interval between applications.

For the water control the seeds were treated with the above-mentioned insecticides and pilling chemicals but neither fungicide nor bacterial suspensions were included. Sprays with water were performed at the same time as the foliar fungicides. The fungicide controls consisted of the application of all the agrochemicals mentioned above to seed treatments along with fludioxonil-metalaxyl-M (Maxim $\mathrm{XL}^{\mathrm{TM}}$, Syngenta, Basel, Switzerland; $100 \mathrm{~mL} / 100 \mathrm{~kg}$ of seeds) and carboxin-thiram (Vitavax $^{\mathrm{TM}}$, Arysta-UPL, Mumbai, India; $800 \mathrm{~mL}$ p.c./100 kg of seeds). Foliar sprays for the fungicide control consisted of the application of Carbendazim (Portero $^{\mathrm{TM}}$, UPL, Mumbai, India; 0.6 L/ha) 45 DAP, Azoxystrobin + Cyproconazol (Priori-Xtra ${ }^{\mathrm{TM}}$; Syngenta, Basel, Switzerland; 0.5 L/ha) 46 DAP, Triphenyltin hydroxide (Mertin $400^{\mathrm{TM}}$, Syngenta, Basel, Switzerland; 0.6 L/ha) 121 DAP and PrioriXtra $(0.5 \mathrm{~L} / \mathrm{ha}) 140 \mathrm{DAP}$. Priori-Xtra was mixed with mineral oil (Nimbus $^{\mathrm{TM}}$, Syngenta, Basel, Switzerland; $0.2 \% \mathrm{v} / \mathrm{v}$ ).

The foliar sprays of bacterial suspensions, fungicides and water control were implemented by using a carbon dioxide backpack sprayer with J4-2 hollow cone spray tips under $2.3 \mathrm{kgf} / \mathrm{cm}^{2}$ constant pressure, resulting in a flow rate of $200 \mathrm{~L} / \mathrm{ha}$. Additional agrochemical sprays for the management of insect pests were conducted by self-propelled sprayers, following the recommended instructions for each commercial product.

The incidence of ramulosis was evaluated on cotton plants. Ten plants per row (1 plant $/ \mathrm{m})$ were randomly sampled on each evaluation, totalizing 30 plants (3 rows) per experimental unit. The assessment of disease incidence consisted of visual recognition of typical foliar symptoms present at the two terminal internodes of the main stem of each cotton plant. For the incidence percentage calculation, four evaluations were performed (at 96, 135, 165 and 196 DAP). Data generated from the incidence assessment were subsequently used to calculate the disease by the AUIPC (SHANER; FINNEY, 1977).

The experimental plots were $12 \mathrm{~m}$ in length and 5 rows wide $(8$ seeds $/ \mathrm{m})$. In order to buffer the effect of neighboring plots, data were only collected from the central $10 \mathrm{~m}$ of the 3 middle rows within each plot.

At the end of each assay, the yield per plot was estimated. In addition, cotton samples from each plot were used for fiber quality measurement, with the aid of HVI (High Volume Instruments) equipment from the Brazilian National Center of Cotton Research- Embrapa Algodão (Campina Grande, PB, Brazil). The HVI system evaluates multiple fiber properties and is widely used for marketing purposes in several countries (El Mogahzy et al., 1990). In our study, the main physicalmechanical parameters evaluated were: tenacity strength (STR) (g/tex) and micronaire indices ( $\mu \mathrm{g} /$ in) (MIC) (HOOGERHEIDE et al., 2007).

\section{Data analysis}

All the experiments had four replicates. The repeated experiments in greenhouses were analyzed as a whole experiment (eight replicates). Results from all experiments were submitted to ShapiroWilk test of normality and to the Bartlett test for homogeneity of variance. The greenhouse trials were arranged in a randomized block with a 4x6 factorial design, corresponding to (3) bacterial strains $\mathrm{x}(6)$ application methods plus controls (water control, Fungicide and ASM). The dry-weight mass and AUIPC data were separately submitted to analysis of variance in a two-way factorial scheme of Strains (3) $\mathrm{x}$ Application method (6). The mean values were compared by Tukey`s test $(\mathrm{P}<0.05)$. The field trials were arranged in a randomized complete block design. The second field trial followed a $4 \times 5$ factorial design, consisting of (4) bacterial treatments $\mathrm{x}$ (5) application methods plus controls (water and fungicide). For field experiments, the AUIPC, crop yield and fiber quality parameters were submitted to 
an one-way analysis of variance in the first season. The second season employed a two-way factorial scheme of Bacterial treatments (4) x Application methods (5). The means were compared according to Tukey`s test $(\mathrm{P}<0.05)$.

\section{RESULTS AND DISCUSSION}

The GenBank BLAST tool reported that the strain UFLA401 showed $99 \%$ similarity with Bacillus velezensis strain NKG-1, $B$. amyloliquefaciens subsp. amyloliquefaciens KHG19 and B. subtilis strain ATCC 19217. The first one is likely the species name that should be adopted since this is a new species that has emerged from the $B$. amylolicefaciens species complex.

In the greenhouse assays, all bacterial strains reduced the AUIPC regardless of application method, compared to the control with water $(\mathrm{P}<$ 0.05). However, the highest reduction in AUIPC was found using the fungicide pyraclostrobin (Figure 1a). B. amyloliquefaciens UFLA285 reduced the disease by $62.1 \%$ when applied as foliar spray or seed treatment followed by foliar spray. The strains B.velezensis UFLA401 and P. lentimorbus MEN2 reduced the disease by $56.6 \%$ and $45.7 \%$, respectively, no mattering which application method was used. The application of ASM reduced the AUIPC by $68.5 \%$ (Figure 1a). On the other hand, shoot dry weight resulted after fungicide treatment was similar to the weight after treatment with any of the bacteria and higher than the control with water ( $\mathrm{P}$ $<0.05)$, while the ASM control reduced the aerial part dry weight $(\mathrm{P}<0.05)$ (Figure $1 \mathrm{~b})$. Therefore, biocontrol with the bacterial strains used here was able to reduce ramulosis more effectively than the chemical fungicide recommended against CGC. Bacillus strains used in biological control usually employ multiple mechanisms to act against plant pathogens (REISS; JØRGENSE, 2017). Furthermore, biocontrol agents promote the reduction of chemical applications and help to avoid resistance selection in plant pathogens (LIMA et al., 2006). Although seed treatment with $B$. amylolicefaciens UFLA285 and $P$. lentimorbus MEN2 have previously prevented the infection by Xanthomonas axonopodis pv. malvacearum, CGC and Rhizoctonia solani (MEDEIROS et al., 2008; MEDEIROS et al., 2011; MARTINS et al., 2013), here we have provided information that other application methods as foliar application and drenching improved the reduction of ramulosis. The use of a defense inducer (ASM) was not as effective as the use of bacterial strains (Figure 1). Usually, the activation of defense mechanisms demands metabolic costs from the plant (STRAUSS et al., 2002), which may be alleviated by the mechanism of growth promotion when bacterial strains are applied (OLIVEIRA; VARANDA; FÉLIX, 2016; GOWTHAM et al., 2018).

Field assays in the 2008/2009 and 2009/2010 seasons showed that all the treatments reduced AUIPC compared to control with water. In $2008 / 2009$, the application of $B$. velezensis UFLA401 by foliar spray reduced the AUIPC more than the other treatments, followed by the fungicide application treatment $(\mathrm{P}<0.05)$. The application of $B$. velezensis UFLA401 and the application of fungicide reduced the incidence of ramulosis by $22.3 \%$ and $13.1 \%$, respectively compared to the control with water (Table 1). In the 2009/2010 season, seed treatment + two sprays was the best method of application of the bacterial suspension to reduce the ramulosis AUIPC, except for $B$. amylolicefaciens UFLA285 which showed the same pattern for all application methods $(\mathrm{P}<0.05)$ (Figure $2 a)$. However, in $2009 / 2010$ the fungicide reduced $72 \%$ of the ramulosis AUIPC compared to control with water. The combination of two strains did not increase the control of ramulosis considering all application methods in both seasons (Table 1, Figure 2a). 
Bacillus amyloliquefaciens UFLA285

Paenibacillus lentimorbus MEN2

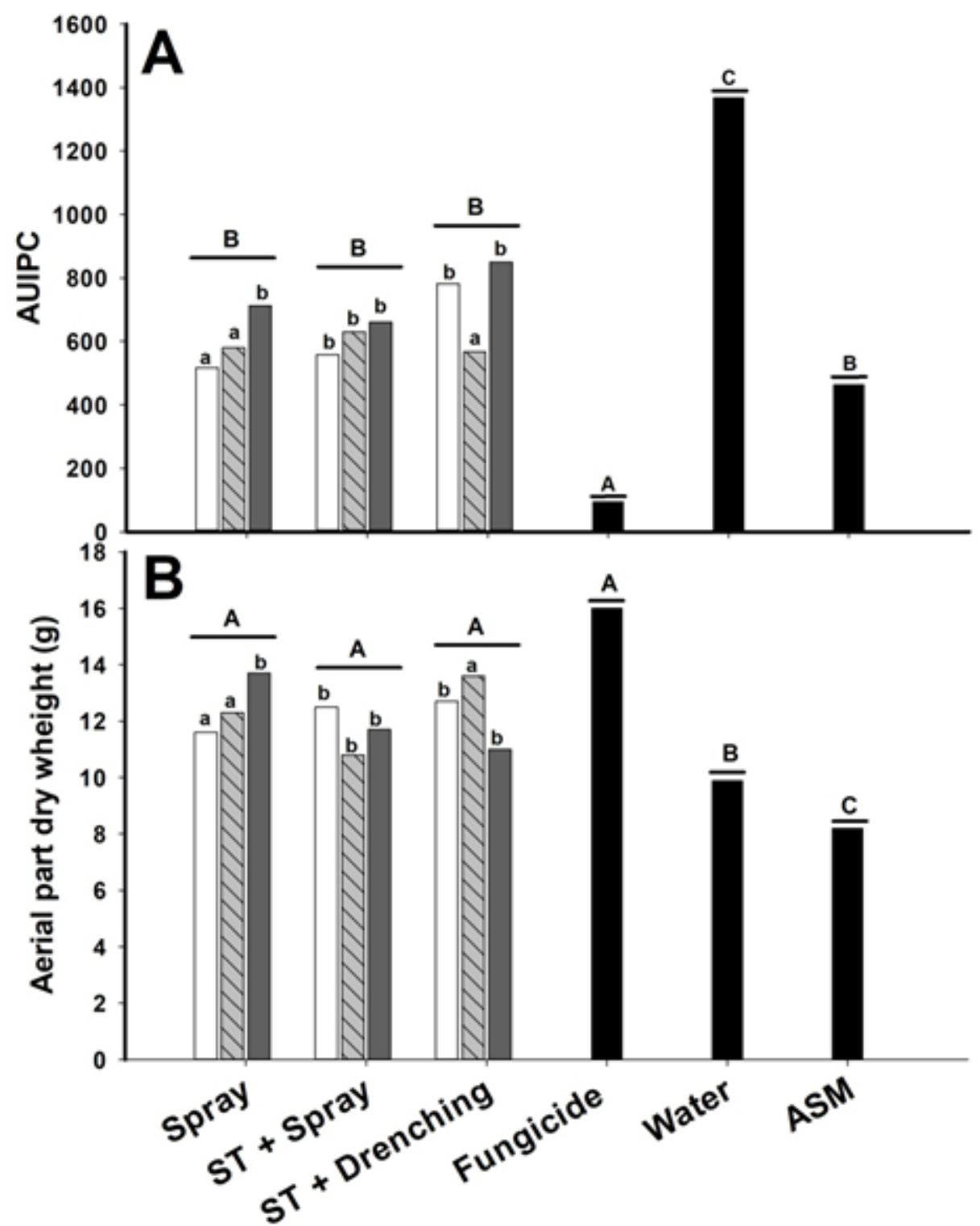

Figure 1. Efficacy of endospore-forming bacteria applied through foliar spray (Spray), seed treatment (ST) followed by foliar spray (ST+Spray) or seed treatment followed by soil drench (ST+Drenching) under greenhouse conditions. A) Ramulosis (Colletotrichum gossypii var. cephalosporioides) incidence analyzed as area under the disease progress curve for incidence (AUIPC). B) Shoot dry weight. Black bars show the means of the controls: Fungicide (Pyraclostrobin), ASM (Acibenzolar-S-methyl) and water. Capital letters compare bacteria application methods with the controls (black bars) and small letters compare the bacterial strains, according to Tukey's test $(\mathrm{P}<0.05)$. These are results are average of 2 experiments carried out under the same conditions and treatments. 
Table 1. Efficacy of endospore-forming bacteria on control of ramulosis (Colletotrichum gossypii var. cephalosporioides) (AUIPC) $)^{\mathrm{a}}$, cotton yield and fiber quality-related variables: fiber strength (STR) and micronaire (MIC). Treatments were applied by foliar spray in the first season (2008/2009).

\begin{tabular}{lcccc}
\hline Treatments & AUIPC (\%) & $\begin{array}{c}\text { Yield } \\
\text { (ton/ha) }\end{array}$ & STR & MIC \\
\hline Bacillus velezensis UFLA401 & $10420.0 \mathrm{a}$ & $4000.0 \mathrm{c}$ & $28.8 \mathrm{ab}$ & $3.7 \mathrm{bc}$ \\
Bacillus amylolicefaciens UFLA285 & $12350.0 \mathrm{~cd}$ & $5218.7 \mathrm{bc}$ & $27.8 \mathrm{ab}$ & $3.8 \mathrm{bc}$ \\
Paenibacillus lentimorbus MEN2 & $12558.3 \mathrm{~cd}$ & $5262.5 \mathrm{ab}$ & $28.4 \mathrm{ab}$ & $4.0 \mathrm{ab}$ \\
UFLA401+MEN2 & $13017.5 \mathrm{de}$ & $5250.0 \mathrm{bc}$ & $29.2 \mathrm{a}$ & $4.2 \mathrm{a}$ \\
Chemical fungicides $^{\mathrm{b}}$ & $11745.0 \mathrm{~b}$ & $5562.5 \mathrm{a}$ & $27.4 \mathrm{~b}$ & $3.8 \mathrm{bc}$ \\
Water control $^{13522.5 \mathrm{e}}$ & $5050.0 \mathrm{bc}$ & $28.6 \mathrm{ab}$ & $3.5 \mathrm{c}$ \\
\hline
\end{tabular}

${ }^{\text {a }}$ Area under the disease progress curve for incidence (AUIPC) determined according to Shaner and Finney (1977) from disease assessments (at 96, 135, 165 and 196 DAP). Treatments followed by the same letters are statically the same according to Tukey's test $(\mathrm{P}<0.05)$.

${ }^{\mathrm{b}}$ Chemical fungicides used were fludioxonyl-metalaxyl-M (Maxim XL ${ }^{\mathrm{TM}}$, Syngenta) and carboxin-thiram (Vitavax ${ }^{\mathrm{TM}}$, Arysta-UPL) by seed treatment and foliar sprays of Carbendazim (Portero ${ }^{\mathrm{TM}}$, UPL,), Azoxystrobin+Cyproconazol (Priori-Xtra ${ }^{\mathrm{TM}}$, Syngenta) and Triphenyltin hydroxide (Mertin $400^{\mathrm{TM}}$, Syngenta).

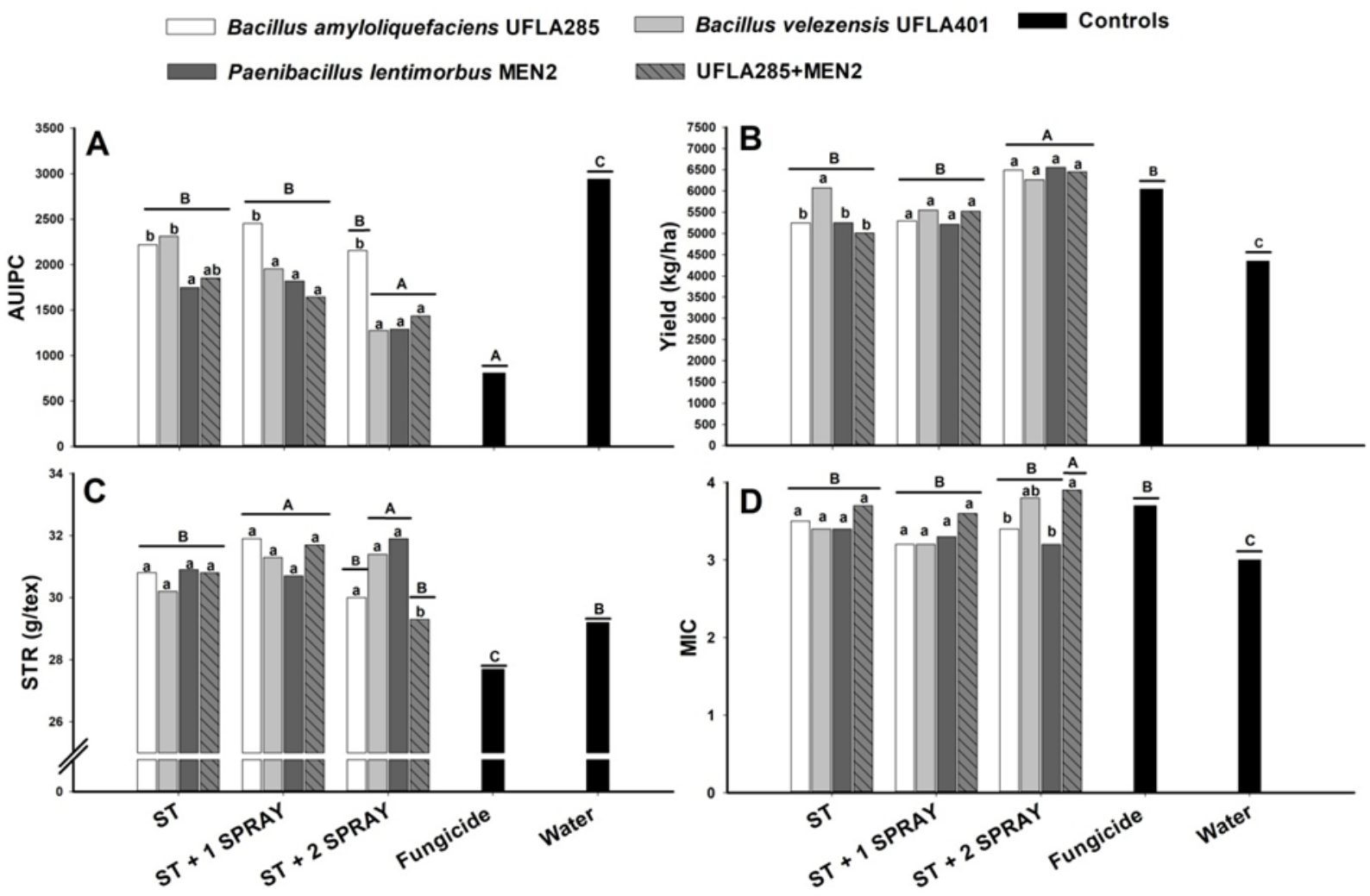

Figure 2. Field efficacy of different application methods of bacterial antagonists on the control of cotton ramulosis (Colletotrichum gossypii var. cephalosporioides) and on physical properties of cotton fibers. A) Ramulosis incidence progress (at 96, 135, 165 and 196 DAP) measured as the area under the disease progress curve for incidence (AUIPC) obtained according to Shaner and Finney (1977). B) Cotton yield estimated as $\mathrm{kg} / \mathrm{ha}$. C) fiber resistance (STR). D) micronaire indices $(\mathrm{MIC}) . \mathrm{ST}=$ Seed treatment; Spray $=$ Foliar spray, ST + spray $=$ seed treatment followed by foliar spray. Black bars show the means of the controls: Fungicide (fludioxonyl-metalaxyl-M and carboxin-thiram by seed treatment and foliar sprays of Carbendazim, Azoxystrobin+Cyproconazol and Triphenyltin hydroxide) and water. Capital letters compare the bacteria application methods with controls and small letters compare bacterial strains, according to Tukey's test ( $\mathrm{P}<$ 0.05). These are results from the second season (2009/2010). 
Although we did not test the bacterial strains against other cotton pathogens, such strains have already demonstrated broad-spectrum disease protection especially against soil-borne diseases caused by $R$. solani, Colletotrichum gossypii, Fusarium spp. and Pythium ultimum (WANG et al., 2004; ERDOĞAN et al., 2016). However, those works have usually been conducted in regions where the ramulosis does not have the significant impact on cotton production that it does in South American countries (MORENO; BURBANO, 2017). Thus, research concerning ramulosis biological control is scarce in field conditions in important regions of cotton production. Here we found efficient biological control of ramulosis in field conditions by applying the bacteria either as seed treatment or foliar sprays. More than six sprays of fungicide are usually necessary to significantly reduce the effect of CGC. Moreover, the CGC might acquire resistance to the disease management practices current applied. Therefore, having in hand an extra tool to control CGC, such as a product based on an endosporeforming bacterium is of utmost importance. Bacillus ability to survive in foliar surface conditions and the its multiple antagonists mechanisms increases the chances of success against foliar pathogens (REISS; JØRGENSE, 2017; FIRA et al., 2018).

In the first season (2008/2009), the application of chemical fungicides promoted higher yield than other treatments (Table 1). The field assay of the second season $(2009 / 2010)$ demonstrated that the best yield performance was achieved by seed treatment + two sprays $(\mathrm{P}<0.05)$ with an average of $6442.2 \mathrm{~kg} / \mathrm{ha}$, but all treatments reached higher values than the water control (Figure $2 b$ ). Thus, seed treatment + two sprays boosted CGC control by using $B$. velezensis UFLA401 and $P$. lentimorbus MEN2 alone in combination (Figure 2a), which consequently increased the yield by $49 \%$ (Figure 2b). Although $B$. amylolicefaciens UFLA285 did not reduce the impact of ramulosis with the same efficiency as the other strains, B. amylolicefaciens UFLA285 resulted in similar yield to the others (Figure 2b). Therefore, the growth promotion provided by $B$. amylolicefaciens UFLA285 (Figure 1b) may be enough to increase cotton yields, as previously demonstrated in other pathosystems (MARTINS et al., 2018a). Furthermore, the use of two different bacterial strains or different biocontrol agents by different application methods may results in synergistic activity due to complementation of nutrient requirement niches and mechanisms (RUANO-ROSA et al., 2014; LAREEN; BURTON; SCHÄFER, 2016).

Although it is not clear which mechanisms could be involved in the activities of $B$. velezensis UFLA401 and $P$. lentimorbus MEN2, transcriptomic studies of $B$. amylolicefaciens UFLA285 applied to cottonseed against $R$. solani revealed regulation of 246 genes related to biotic-resistance and drought- tolerance (MEDEIROS et al., 2011), which would add to the sustainability of crop production since cotton is generally produced in regions of rainfall shortage (FONTES et al., 2006). The same strain also assured higher yield in common beans (Phaseolus vulgaris L.) grown under drought stress conditions (MARTINS et al., 2018a). Other strains of $B$. amiloquefaciens act by different mechanisms against plant pathogens, such as competition and production of antimicrobial lipopeptides (MOREIRA et al., 2015; MONTEIRO et al., 2016). Furthermore, metabolites toxic to $C$. gossypii have already been extracted from Bacillus species implying antibiosis as a relevant mechanism against the fungal development (NAWAZ et al., 2018).

There were significant differences between treatments regarding cotton fiber quality (Table 1; Figure 2). The combination of $B$. velezensis UFLA401 $+P$. lentimorbus MEN2 increased the fiber resistance (STR) compared to the other treatments $(\mathrm{P}<0.05)$ in the first season (Table 1$)$. In the second season the seed treatment + one foliar spray was enough to increase the STR compared to the water and fungicides controls for all bacterial strains $(\mathrm{P}<0.05)$ (Figure 2c). The fungicide treatment resulted in a lower STR value than bacterial treatments and the control with water $(\mathrm{P}<$ 0.05 ) (Figure 2c). The STR value was increased by bacterial application and reached values higher than $30 \mathrm{~g} /$ tex, which is the value required for standard to good quality fabric (CARVALHO et al., 2015). The combination of $B$. velezensis UFLA401 $+P$. lentimorbus MEN2 increased the micronaire indices (MIC) by $26 \%$ compared to the control with water in the first season (Table 1). In the 2009/2010 season all application methods differ from control with water in terms of MIC. The combination of $B$. velezensis UFLA401 $+P$. lentimorbus MEN2 by seed treatments + two sprays provided the highest MIC compared to all other treatments increasing the MIC by $17.9 \%$ more than the control with water $(\mathrm{P}<$ 0.05 ) (Figure 2d). Therefore, even if the biocontrol agents did not ensure disease protection significantly higher than that provided by the fungicide spray, the biological treatments should be combined with the fungicide to avoid the undesirable effects on fiber quality produced when only fungicide is used. Future works should also consider combinations of the most promising biocontrol agents, with the objective of eventually reducing chemical application and making management more cost-effective.

All these results support the strategy of using bacterial strains as biological control agents in both conventional and organic cotton production. There are few plant protection options in organic cotton production, mainly for the improvement in fiber quality and disease reduction (YAO et al., 2006). Furthermore, cotton is one of the most demanding crops in terms of agrochemical inputs, which are responsible for adverse effects on the environment 
(BACHMANN 2012; FORSTER et al., 2013). A reduction in chemical applications impacts not only the environment but also the production costs. Fungicides are responsible for a large proportion of disease control expenditure, which would be minimized by fewer applications. The replacement of chemical applications by biocontrol agents also reduces resistance selection on plant pathogens (LIMA et al., 2006). All these aspects combined with the increase in demand for organic cotton (RIEPLE; SINGH, 2010), open doors to the use of endosporeforming bacterial strains $B$. velezensis UFLA401, $B$. amyloliquefaciens UFLA285 or $P$. lentimorbus MEN2 in the management of conventional and organic cotton systems to control ramulosis, promote plant growth and increase the fiber quality. The advantages of using these bacteria should be more exploited in the organic production of cotton to emphasize the worth of using them.

\section{CONCLUSIONS}

The strains $B$. velezensis UFLA401, $B$. amiloquefaciens UFLA285 and Paenibacillus MEN2 controlled CGC in greenhouse and field conditions. Generally, $B$. velezensis UFLA401 and the combination of $B$. velezensis UFLA401 $+P$. lentimorbus MEN2 produced the best results in ramulosis reduction, cotton yield and fiber quality, performing even better than the standard fungicide control.

\section{AKNOWLEDGMENTS}

The authors are thankful to Fundação de Amparo à Pesquisa do Estado de Minas Gerais FAPEMIG (APG-2916-3.09-07) for financial support. The authors also acknowledge the support for the field trials of Laboratório de Biocontrole Farroupilha (Patos de Minas, Brazil) and to the researcher Tarcisio Gondim from Embrapa Algodão (Campina Grande, Brazil).

\section{REFERENCES}

ARAÚJO, A. E. D. et al. Efeito de diferentes níveis de Colletotrichum gossypii South var. cephalosporioides Costa, em plantas de algodão no campo e sua incidência nas sementes. Summa Phytopathologica, 35: 310-315, 2009.

BACHMANN, F. Potential and limitations of organic and fair trade cotton for improving livelihoods of smallholders: evidence from Central Asia. Renewable agriculture and food systems, 27: 138-147, 2012.
BARROCAS, E. N.; CRUZ, J. M.; CARVALHO, M. A. Seleção do local de aplicação e do estádio fenológico do algodoeiro para inoculação do agente da ramulose. Bragantia, 70: 586-589, 2011.

CAMPANHOLA, C.; BETTIOL, W. Panorama sobre o uso de agrotóxicos no Brasil. In: CAMPANHOLA, C.; BETTIOL, W. (Eds.). Métodos alternativos de controle fitossanitário. Jaguariuna: EMBRAPA Meio Ambiente, 2003. cap. 1, p.13-52.

CARVALHO, L. P. et al. Estabilidade e adaptabilidade de genótipos de algodão de fibra colorida quanto aos caracteres de fibra. Ciência Rural, 45: 598-605, 2015.

DIEZ, A. A. E. et al. Is a signaling peptide that stimulates sporulation and crylAa expression in Bacillus thuringiensis but not in Bacillus subtilis. Applied Microbiology and Biotechnology, 76: 203209, 2007.

EL MOGAHZY, Y. E. et al. A statistical approach for determining the technological value of cotton using HVI fiber properties. Textile Research Journal, 60: 495-500, 1990.

ERDOĞAN, O. et al. Biological Control of Cotton Seedling Diseases by Fluorescent Pseudomonas spp. Tarım Bilimleri Dergisi, 22: 398-407, 2016.

FIRA, D. et al. Biological control of plant pathogens by Bacillus species. Journal of Biotechnology, 285: 44-55, 2018.

FONTES, E. et al. The cotton agricultural context in Brazil. In: HILBECK, A.; ANDOW, D. A.; FONTES, E. M. G. (Eds.). Environmental risk assessment of genetically modified organisms, Zürich: CABI, 2006. v. 2, cap. 2. p. 21-66.

FORSTER, D. et al. Yield and economic performance of organic and conventional cottonbased farming systems-results from a field trial in India. PLoS One, 8: e81039, 2013.

FREIRE, E. C. Algodão no cerrado do Brasil. 1. ed. Brasília, DF: Abrapa, 2007, 918 p.

GOWTHAM, H. G. et al. Plant growth promoting rhizobacteria-Bacillus amyloliquefaciens improves plant growth and induces resistance in chilli against anthracnose disease. Biological Control, 126: 209217,2018

HILLOCKS, R. J. Cotton diseases and their control in the $21^{\circ}$ century. In: Wakelyn, J.; Rafiq, C. M. (Ed.). Cotton: Technology for the 21st century. Washington DC: International Cotton Advisory 
Committee, 2010. cap. 4, p. 155-180.

HOOGERHEIDE, E. S. S. et al. Correlações e análise de trilha de caracteres tecnológicos e a produtividade de fibra de algodão. Pesquisa Agropecuaria Brasileira, 42: 1401-1405, 2007.

IRIZARRY, I.; WHITE, J. F. Application of bacteria from non-cultivated plants to promote growth, alter root architecture and alleviate salt stress of cotton. Journal of Applied Microbiology, 122: 1110-1120, 2017.

ISHIDA, A. K. N. et al. Rizobactérias no controle da mancha angular do algodoeiro. Ciência e Agrotecnologia, 32:149-156, 2008.

LAREEN, A.; BURTON, F.; SCHÄFER, P. Plant root-microbe communication in shaping root microbiomes. Plant Molecular Biology, 90: 575$587,2016$.

LAZO, G. R.; GABRIEL, D. W. Conservation of plasmid DNA sequences and pathovar identification of strains of Xanthomonas campestris. Phytopathology, 77: 448-453, 1987.

LIMA G. et al. Integration of biocontrol yeast and thiabendazole protects stored apples from fungicide sensitive and resistant strains of Botrytis cinerea. Postharvest Biology and Technology, 40: 301-307, 2006.

MARTINS, S. A. et al. Common bean (Phaseolus vulgaris L.) growth promotion and biocontrol by rhizobacteria under Rhizoctonia solani suppressive and conducive soils. Applied Soil Ecology, 127: 129 $-135,2018 \mathrm{a}$.

MARTINS, S. J. et al. Biological control of bacterial wilt of common bean by plant growth-promoting rhizobacteria. Biological Control, 66: 65-71, 2013.

MARTINS, S. J. et al. Plant-associated bacteria mitigate drought stress in soybean. Environmental Science and Pollution Research, 25: 13676-13686, 2018b.

MEDEIROS, F. et al. Bacillus spp. to manage seedborn Colletotrichum gossypii var. cephalosporioides damping-off. Phytopathology, 98: 102-103., 2008.

MEDEIROS, F. H. et al. Transcriptional profiling in cotton associated with Bacillus subtilis (UFLA285) induced biotic-stress tolerance. Plant and Soil, 347: 327-337, 2011.

MONTEIRO, F. P. et al. Effect of temperature, $\mathrm{pH}$ and substrate composition on production of lipopeptides by Bacillus amyloliquefaciens 629 .
African Journal of Microbiology Research, 10: 1506-1512, 2016.

MONTEIRO, J. E. B. et al. Development of ramulosis disease of cotton under controlled environment and field conditions. Phytopathology, 99: 659-665, 2009.

MOREIRA, Z. P. M. et al. Host and tissue preferences of Enterobacter cloacae and Bacillus amyloliquefaciens for endophytic colonization. African Journal of Microbiology Research, 9: 1352-1356, 2015.

MORENO, M. M.; BURBANO, F. O. Dynamics of cotton ramulosis epidemics caused by Colletotrichum gossypii var. cephalosporioides in Colombia. European Journal of Plant Pathology, 149: 443-454, 2017.

NAWAZ, H. H. et al. Evaluation of antifungal metabolites activity from Bacillus licheniformis OE04 against Colletotrichum gossypii. Pesticide Biochemistry and Physiology, 146: 33-42, 2018.

OLIVEIRA, M. D. M.; VARANDA, C. M. R.; FÉLIX, M. R. F. Induced resistance during the interaction pathogen $\mathrm{x}$ plant and the use of resistance inducers. Phytochemistry Letters, 15: 152-158, 2016 .

REISS, A; JØRGENSEN A. L. Biological control of yellow rust of wheat (Puccinia striiformis) with Serenade ${ }^{\circledR}$ ASO (Bacillus subtilis strain QST713). Crop Protection, 93: 1-8. 2017.

RIEPLE, A.; SINGH, R. A value chain analysis of the organic cotton industry: The case of UK retailers and Indian suppliers. Ecological Economics, 69: 2292-2302, 2010.

RUANO-ROSA, D. et al. Biological control of avocado white root rot with combined applications of Trichoderma spp. and rhizobacteria. European Journal of Plant Pathology, 138: 751-762, 2014.

SALUSTIANO, M. E. et al. The etiological agent of cotton ramulosis represents a single phylogenetic lineage within the Colletotrichum gloeosporioides species complex. Tropical Plant Pathology, 39: 357 $-367,2014$

SHAFI, J.; TIAN, H.; JI, M. Bacillus species as versatile weapons for plant pathogens: a review. Biotechnology \& Biotechnological Equipment, 31: 446-459, 2017.

SHANER, G.; FINNEY, R. The effect of nitrogen fertilization on the expression of slow-mildewing 
resistance in Knox wheat. Phytopathology, 67: 1051 $-1056,1977$.

SILVA, J. C. et al. Management of Ramularia leaf spot on cotton using integrated control with genotypes, a fungicide and Trichoderma asperellum. Crop Protection, 94: 28-32, 2017.

STRAUSS, S. Y. et al. Direct and ecological costs of resistance to herbivory. Trends in Ecology \& Evolution, 17: 278-285, 2002.

VERSALOVIC, J. et al. Distribution of repetitive DNA sequences in eubacteria and application to finerpriting of bacterial enomes. Nucleic Acids Research, 19: 6823-6831, 1991.

VERSALOVIC, J. et al. Genomic fingerprinting of bacteria using repetitive sequence-based polymerase chain reaction. Methods in Molecular and Cellular Biology, 5: 25-40, 1994.

WANG, C. et al. Q. Colonization and persistence of a plant growth-promoting bacterium Pseudomonas fluorescens strain CS85, on roots of cotton seedlings. Canadian Journal of Microbiology, 50: 475-481, 2004.

WILSON, K. Preparation of Genomic DNA from Bacteria. In: Ausubel, F.M., Brent, R., Kingston, R. E.; Moore, D. D.; Seidman, J. G.; Smith, J. A.; Struhl, K. (Eds.). Current Protocols in Molecular Biology. New York, NY: Wiley \& Sons, 1987. cap. 24, p. 241-245.

YAO, A. et al. Effect of FZB 24® Bacillus subtilis as a biofertilizer on cotton yields in field tests. Archives of Phytopathology and Plant Protection, 39: 323-328, 2006.

YASMIN, S.; HAFEEZ, F. Y.; RASUL, G. Evaluation of Pseudomonas aeruginosa $\mathrm{Z5}$ for biocontrol of cotton seedling disease caused by Fusarium oxysporum. Biocontrol science and technology, 24: 1227-1242, 2014.

ZANCAN, W. L. et al. Cotton in Brazil: Importance and Chemical Control of Bolls Rot. In: Mizuho, N. (Ed.). Fungicides- Showcases of Integrated Plant Disease Management from Around the World. London: InTech, 2013. cap. 12, p. 136-152. 